\title{
"SEUS CORPOS VÃO FALAR DE SUAS IDENTIDADES": DISCURSOS DE PROFISSIONAIS DA EDUCAÇÃO INFANTIL FACE ÀS RELAÇÕES ÉTNICO-RACIAIS
}

\author{
"THEIR BODIES WILL REVEAL THEIR IDENTITIES": \\ DISCOURSES OF EARLY CHILDHOOD EDUCATION \\ PROFESSIONALS IN THE FACE OF RACE AND \\ ETHNIC RELATIONS
}

\author{
Gisele Romildes Maçaneiro ${ }^{1}$ \\ [https://orcid.org/0000-0002-7530-2674] \\ Cyntia Bailer ${ }^{2}$ \\ [https://orcid.org/0000-0002-9049-8003] \\ DOI: 10.30612/raido.v15i37.14662
}

\begin{abstract}
RESUMO: Este artigo reporta um recorte de uma pesquisa de mestrado defendida em um Programa de Pós-graduaçâo em Educaçăo que tem como base a discussâo da educaçâo para as relaçōes étnico-raciais. A partir de análise bibliográfica e coleta de dados com questionário realizado com profissionais da Educaçăo Infantil da Prefeitura Municipal de Florianópolis (SC) via e-mail, que trabalharam com crianças haitianas no ano letivo de 2020, busca-se investigar os discursos dessas profissionais perante relaçōes étnicoraciais naturalizadas no interior das instituiçôes de educaçâo infantil face à presença de crianças negras e imigrantes. Como resultados, os dados revelaram a presença do mito da democracia racial atrelado de forma naturalizada em ambientes educativos na sociedade brasileira bem como a invisibilizaçáo do diferente, tendo por base nas instituiçôes um trabalho diante do padrăo eurocêntrico e embranquecido abafando identidades de crianças negras e imigrantes, trazendo à tona a necessidade de formaçáo docente diante das relaçôes étnico-raciais, da diversidade e da diferença como princípio norteador para iniciar as transformaçōes necessárias ao que está posto e enraizado historicamente.
\end{abstract}

Palavras-chave: Educaçăo infantil. Relaçôes étnico-raciais. Crianças haitianas. Formaçâo docente.

ABSTRACT: This article reports part of a master's research study defended in a Graduate Program in Education that is based on the discussion of education in the face of race and

1 Mestre em Educaçăo pelo Programa de Pós-graduaçăo em Educaçăo da Universidade Regional de Blumenau (FURB) (2021). Bolsista UNIEDU (Programa de Bolsas Universitárias de Santa Catarina) durante a execuçáo do trabalho aqui apresentado. Professora na Prefeitura Municipal de Florianópolis (PMF). Contato: gisele.macaneiro@prof.pmf.sc.gov.br. Orcid: https://orcid.org/0000-0002-7530-2674.

2 Doutora em Estudos da Linguagem pela Universidade Federal de Santa Catarina. Docente no curso de Letras e no Programa de Pós-Graduaçāo em Educaçâo da FURB. Contato: cbailer@furb.br. Orcid: http:// orcid.org/0000-0002-9049-8003. 
ethnic relations. Based on bibliographic analysis and data collection with a questionnaire carried out with early childhood education professionals from the Municipality of Florianópolis, state of Santa Catarina, Brazil, through e-mail, who worked with Haitian children in the 2020 school year, we seek to investigate these professionals' discourse in the face of race and ethnic relations that seem to be naturalized inside early childhood education institutions with the presence of black and immigrant children. As results, the data revealed the presence of the myth of racial democracy tied, in a naturalized way, to educational environments in the Brazilian society as well as the invisibility to the different, based on the institutions' work in the face of an Eurocentric and whitened standard, suppressing such black and immigrant children's identities, bringing to light the need for teacher education related to racial and ethnic relations, diversity and difference as guiding principles to initiate the necessary changes to what is historically rooted.

Keywords: Early childhood education. Race and ethnic relations. Haitian children. Teacher education.

\section{INTRODUÇÃO}

O presente artigo apresenta um recorte de uma pesquisa defendida em um Programa de Pós-graduaçăo em Educaçăo que tem por objetivo investigar os discursos de profissionais da educaçăo infantil da rede de ensino municipal de Florianópolis face à presença de crianças haitianas, ou seja, negras e imigrantes, no interior dessas instituiçôes de educaçâo infantil. Trata-se de uma pesquisa qualitativa que procurou evidenciar a análise de microprocessos com o estudo de açóes individuais e em grupo, diante da obtençâo de dados descritivos (GODOY, 1995; MARTINS, 2004).

A pesquisa foi realizada no ano de 2020 no contexto da pandemia mundial de COVID-19, com a suspensâo das atividades escolares presenciais como medida de contençăo do vírus que se prolifera principalmente pela aglomeraçăo de pessoas e contato físico. Inicialmente, a pesquisa de cunho etnográfico precisou ser alterada para se tornar exequível no período destinado ao término do mestrado. Como possibilidade para sua conclusâo se utilizou de questionários enviados às profissionais da Educaçâo Infantil via e-mail.

Considerando o crivo ético que toda pesquisa que envolve seres humanos precisa passar, esta pesquisa tem por fundamentos o "[...] respeito à pessoa, ao conhecimento, respeito aos valores democráticos, respeito à qualidade da pesquisa educacional e respeito à liberdade acadêmica" (MAINARDES, 2017, p. 167). Deste modo, a presente pesquisa foi avaliada pelo Comitê de Ética na Pesquisa em Seres Humanos da universidade e obteve aprovaçáo em 21/02/2020, sob o parecer $n^{\circ} 3.852 .941$. Dessa forma, em consonância com os princípios éticos, para manter a identidade das profissionais desta pesquisa em anonimato, os nomes utilizados sâo nomes fictícios, escolhidos pelos próprios participantes do estudo. Assim, demonstra-se o cuidado ético do pesquisador para o bem estar do participante e garantia de seus direitos.

Segundo Gil (2008), a utilizaçăo de um questionário em uma pesquisa precisa ter por eficácia a traduçâo dos objetivos do estudo, que pode em sua utilizaçăo contar com a vantagem de atingir um grande número de pessoas simultaneamente, mesmo que estejam dispersas geograficamente, bem como como na impossibilidade de contato físico, como ocorreu com este estudo em decorrência da pandemia de COVID-19. No entanto, o uso de questionários oferece também desvantagens diante da impossibilidade 
de ajudar o participante em questóes mal compreendidas e assim nâo ter retornos ou retornos sem respostas completas e coerentes. Tais contratempos foram sentidos nesta pesquisa, mas mesmo diante destes se obteve ainda um número importante de dados a serem discutidos.

Nesse contexto, cinco instituiçôes de educaçăo infantil participaram do estudo. Essas cinco instituiçōes foram escolhidas por terem crianças haitianas matriculadas no ano de 2020. Trinta profissionais aceitaram responder ao questionário enviado por e-mail. Entre essas trinta profissionais, há participantes autodeclaradas racialmente entre negras, brancas ou como nada consta. Em relaçâo ao tempo de atuaçăo na educaçâo infantil, há profissionais com experiência entre um ano e trinta anos. Em relaçâo à sua formaçăo, há profissionais com graduaçăo, especializaçăo e mestrado. E em relaçăo à formaçăo sobre as relaçôes étnico-raciais, há profissionais com algum tipo de formaçâo e também profissionais que nunca tiveram a oportunidade de participar de alguma formaçāo sobre esta temática.

Considera-se relevante destacar que somente nestas cinco unidades o número total de crianças haitianas matriculadas no ano letivo de 2020 era de 41 crianças e que segundo a Gerência de Formaçâo Continuada (GFC) da Prefeitura Municipal de Florianópolis (PMF) às pesquisadoras, o número total de crianças haitianas matriculadas em 2020 na Educaçăo Infantil é de 56 no total. Dessa forma, trata-se de uma demanda relevante para se refletir e debater em pesquisas quanto à visibilizaçăo ou invisibilizaçâo dessas crianças nas unidades de educaçăo infantil, considerando que săo crianças negras e imigrantes, provenientes de um país historicamente assolado em crise e carregado de estereótipos desde sua colonizaçăo.

Para compreender como os haitianos chegaram à Florianópolis, é preciso conhecer um pouco da história de seu país de origem. O Haiti é uma ex-colônia francesa riquíssima que gerou muita abastança à França e por meio de uma revoluçâo transformou ex-escravos, negros, analfabetos e descendentes de africanos em grandes heróis, comandantes, chefes de estado, libertos e independentes. Esses indivíduos subalternizados, segundo Scamaral (2006), cansados das atrocidades sofridas por uma escravidáo que os colocou como sujeitos selvagens e incivilizados, conseguiram diante da vitória nesta revoluçấo uma inversâo da ordem estabelecida perante negros e escravos, algo inimaginável aos colonizadores. Munidos sob ideais da revoluçăo francesa (liberdade, igualdade, fraternidade e independência), no Haiti escravos começaram uma revoluçáo e em 1804 diante da vitória sob o exército de Bonaparte líderes negros proclamaram a independência do Haiti.

Alguns pontos pós-revoluçăo precisam ser apresentados para se entender como uma colônia, da mais produtiva, se transformou em um país tăo pobre, como: disputas internas, indenizaçăo à França, autoritarismo, golpes e corrupçăo por parte de seus governantes, intervençóes militares estrangeiras e desastres naturais (terremoto 2010 e dois furaçōes em 2012), fizeram do Haiti um país de imigraçăo forçada com uma profunda crise econômica e social que assolou o país e fez sua populaçăo buscar outros países para um recomeço (JAMES, 2000; MAGALHÂES, 2015).

As razóes que deram início ao fluxo migratório do Haiti para o Brasil săo imprecisas, mas algumas hipóteses podem ser levantadas. Segundo Magalhăes (2015), a presença do exército brasileiro na força de paz no Haiti e as oportunidades de trabalho 
com obras para a Copa do Mundo de 2014, as Olimpíadas de 2016 e a construçấo de hidrelétricas. 0 processo de chegada ao Brasil, na maioria das vezes, se dava pela fronteira norte do país (Amazonas e Acre). A vinda dos haitianos para Santa Catarina inicialmente se deu por uma forte atuaçăo de três empresas catarinenses (Multilog, Ambiental e Embrasul), no recrutamento e contrataçăo de força de trabalho, que inicialmente chegaram ao Vale do Itajaí, mas depois esses imigrantes se espalharam pelo estado vindos em grande número para Florianópolis. Esses trabalhadores haitianos, ao se assentaram em uma regiăo e em um emprego, logo tinham como objetivo trazer do Haiti demais membros de sua família e assim seus filhos passaram a fazer parte da demanda educacional.

Além das dificuldades de colocaçăo no mercado de trabalho, os imigrantes haitianos deparam-se com discriminaçōes raciais, sociais, linguísticas, religiosas e até xenofóbicas, no sentido de que vêm de um país subdesenvolvido. Assim, as crianças haitianas (negras e imigrantes) em ambientes educacionais se deparam com instituiçôes marcadas por uma cultura marcada pela imposiçăo europeia do homem branco, que tem sido o modelo e o padrâo na sociedade desde a colonizaçăo do Brasil, ou seja, um país multicultural e multirracial embasado em uma cultura monocultural e monorracial que nâo considera a todos tanto imigrantes haitianos quanto seus próprios nativos.

Partindo do pressuposto de que a luta por uma sociedade igualitária e democrática é dever de todos e náo somente uma luta de grupos racialmente e etnicamente excluídos, as pesquisadoras autodeclaradas brancas pretendem neste artigo se debruçarem a falar sobre o racismo diante dos discursos presentes nas respostas ao questionário, mesmo sem sofrerem tal tipo de racismo. As pesquisadoras se embasam em estudiosos da área, pois o engajamento na luta antirracista deve ser feito por todos, inclusive por brancos que precisam reconhecer seus privilégios, assim como a injustiça e a opressâo a que grupos sociais marginalizados sáo submetidos diante da branquitude imposta a esta sociedade. 0 ensino nas escolas revela um currículo embranquecido, baseado na revoluçăo de brancos: a Revoluçâo Francesa diante da continuidade de um padrăo educacional estabelecido na cultura eurocêntrica, năo dando visibilidade a uma revoluçáo de negros, por exemplo.

Para Ribeiro (2019), o reconhecimento do racismo como um sistema que estrutura a sociedade e desta forma também instituiçôes de educaçâo é o começo para a consciência de que se vive num perverso sistema racial e que assim se deve lutar sempre por mudanças. Desta forma, torna-se de extrema relevância discutir uma educaçáo infantil pautada na diferença e na diversidade, que procure romper com padróes eurocêntricos e embranquecidos ainda tâo presentes e naturalizados na sociedade e em ambientes educativos. Pensar em uma educaçăo antirracista parte do princípio da visibilizaçăo e do reconhecimento ao diferente, compreendendo que năo conseguimos valorizar o que náo conhecemos e, desta forma, repensar a formaçăo docente de faz necessário e urgente.

\section{AS RELAÇÕES ÉTNICO-RACIAIS NA EDUCAÇÃO INFANTIL E A NATURALIZAÇÃO HISTÓRICA DE PADRÕES EUROCÊNTRICOS E EMBRANQUECIDOS}

As relaçôes étnico-raciais estabelecidas na sociedade sâo representaçôes dos padróes históricos estabelecidos por meio de uma cultura eurocêntrica e embranquecida. Portanto, sua compreensăo precisa remontar passos e situaçóes históricas que levaram 
à constituiçăo de uma sociedade racista, preconceituosa, discriminatória e desigual diante de grupos năo identificados nesses padrôes naturalizados socialmente e, portanto, afetam também as estruturas de padrōes nas instituiçōes de educaçăo infantil.

Pensar no desenvolvimento de crianças inseridas em uma sociedade onde o racismo é perpetrado sistematicamente envolve refletir sobre como o educador com interaçôes positivas pode contribuir para mudanças com ênfase a uma educaçăo antirracista, principalmente ao considerar que as crianças năo nascem fundadas no preconceito que é estabelecido por meio de interaçōes sociais negativas diante da identidade racial, étnica e da diferença estabelecida em cada uma. Pensar na criança como sujeito ativo na sociedade com suas identidades dentre cultura, língua, raça, cor, posiçáo social e etnia, exige considerá-la de forma a ser reconhecida e respeitada.

Neste tocante, Schwarcz e Gomes (2018) buscam refletir sobre questōes históricas como a escravidăo que perdurou por quase quatro séculos no Brasil e prolongou seus efeitos até os dias hoje em seus descendentes, tendo como decorrência a inserçăo de uma lei que năo previa nenhum projeto de inclusâo social a fim de redimir desigualdades assentadas e hierarquias naturalizadas, jogando os negros na rua e à própria sorte sem expectativa nenhuma diante desta tal liberdade.

Segundo Almeida (2019), o significado da palavra raça como esta foi criada e difundida explica muito da continuidade por uma luta antirracista até atualmente, pois esta palavra está condicionada ao ato de estabelecer classificaçáo, com a finalidade de colocar distintas categorias entre os seres humanos. A ciência do século XIX legitimou o conceito de raça diante de características físicas e biológicas, já que a pele nâo branca era relacionada a comportamentos imorais e violentos, que indicavam pouca inteligência. Assim se recomendou evitar misturas de raças, já que o mestiço tendia a ser mais 'degenerado'.

No Brasil, a miscigenaçâo entre nativos e imigrantes europeus tinha como objetivo o embranquecimento da populaçăo e o apagamento da raça negra na populaçấo brasileira. Segundo Pereira (2013), o Brasil era conhecido por outros países como um paraíso racial diante das relaçóes interraciais (miscigenaçăo), sendo um faz de conta diante da realidade racista no Brasil. Este mito da democracia racial dificulta até hoje a percepçáo das desigualdades raciais, disfarçando conflitos raciais existentes.

A branquitude na sociedade foi marcada pelo processo de hierarquizaçăo, em que a identidade branca tem como garantia privilégios simbólicos constituídos pelo poder estrutural dos colonizadores e assim a degradaçăo da cultura negra. A sociedade é marcada e padronizada pela imposiçấo da cultura europeia do homem branco, que tem sido o modelo e o padrấo na sociedade desde a colonizaçăo do Brasil. Para Quijano (2005), o espanhol, o português e o europeu năo indicavam mais somente procedência geográfica, mas uma conotaçâo racial, em que as relaçóes de dominaçáo impunham os padrôes de identidade e a Europa atribuía sua hegemonia pelo controle da cultura e da produçăo de conhecimento, o eurocentrismo.

Almeida (2019) relata que já no século XX principalmente pós eventos catastróficos para a humanidade como a segunda guerra mundial e o genocídio nazista perpetrado pela Alemanha, a antropologia engajou-se em provar a autonomia de cada cultura e a inexistência de determinaçóes biológicas. No entanto, ainda nos dias atuais a noçăo de raça constitui fator político para naturalizar desigualdades, 
legitimar a segregaçâo e o genocídio de grupos sociais considerados minoritários, perpetuando, assim, o racismo, o preconceito e a discriminaçăo.

$\mathrm{Na}$ tentativa de combater formas de discriminaçăo racial que levaram a humanidade a promover extermínios, o documento Eliminaçăo de todas as Formas de Discriminaçăo Racial foi assinado em Nova York no ano de 1966 e a Constituiçáo Federal do Brasil de 1988 incluem essa temática. Entre os objetivos fundamentais do Brasil, a Constituiçáo brasileira inclui em seu artigo $3^{\circ}$, inciso IV, o "bem de todos, sem preconceitos de origem, raça, sexo, cor, idade e quaisquer outras formas de discriminaçăo". Na mesma esteira, e em busca de uma educaçăo antirracista, a Lei nº 10.639/2003 alterou as diretrizes e bases da educaçâo nacional (LDB) para incluir no currículo oficial das redes de ensino a obrigatoriedade da temática "História e Cultura Afro-Brasileira". Assim, incluiu "[...] o estudo da História da África e dos Africanos, a luta dos negros no Brasil, a cultura negra brasileira e o negro na formaçăo da sociedade nacional, resgatando a contribuiçâao do povo negro nas áreas social, econômica e política pertinentes à História do Brasil" (BRASIL, 2003, p. 1). Também, a Lei nº 11.645/2008 alterou a LDB para incluir no currículo oficial das redes de ensino a obrigatoriedade da temática "História e Cultura Afro-Brasileira e Indígena", incluindo desta forma dois povos importantes para a formaçâo e desenvolvimento da sociedade brasileira, buscando desta forma o reconhecimento da contribuiçấo desses povos para a identidade nacional.

Esses documentos oficiais sâo importantíssimos para uma educaçâo pautada nas relaçôes étnico-raciais e uma política de açâo afirmativa diante da diversidade brasileira. Mais que uma iniciativa do Estado, é resultado de muita luta do movimento negro em prol da educaçăo. Somente o (re)conhecimento das raízes africanas e da participaçăo do povo negro na construçấo e desenvolvimento da sociedade brasileira poderá contribuir para a superaçăo de mitos diante de discursos impregnados de um povo africano selvagem e de um povo negro marginalizado.

Nesse contexto, indaga-se: será que esses documentos săo debatidos em formaçóes dos docentes e se tem buscado açóes efetivas em prol da diversidade étnica e racial existente? E estas discussōes conseguem trazer à tona a necessidade de visibilizaçăo e reconhecimento da diversidade nas instituiçôes de crianças vivendo e interagindo em um mesmo ambiente? Espera-se poder refletir sobre essas e outras indagaçóes perante os discursos dos docentes a partir das respostas ao questionário desta pesquisa.

\section{REFLETINDO SOBRE DISCURSOS DE PROFISSIONAIS DA EDUCAÇÃO INFANTIL PERANTE AS RELAÇÕES ÉTNICO-RACIAIS}

O modo como as relaçóes étnico-raciais tem se configurado no interior das instituiçôes de educaçăo infantil comumente silenciando e abafando o diferente revela-se como um tema a ser discutido com profissionais de educaçâo infantil em formaçôes. Ressalta-se que esse silenciamento tem por base o desconhecimento da discriminaçâo étnica e racial (GOMES, 2012). Nesse contexto, é relevante refletir sobre os discursos de profissionais da educaçâo perante a educaçăo para as relaçōes étnico-raciais e a visibilizaçăo ou invisibilizaçăo de crianças haitianas nas instituiçóes. Para desvelar essas questóes nos discursos das profissionais, os seguintes questionamentos foram feitos no questionário: "As crianças haitianas sâo vistas pelas demais crianças e pela 
comunidade educativa como diferentes? Já ouviu algum tipo de comentário ou observou alguma forma de discriminação/preconceito na sala entre os coleguinhas? e "como foi a inserçâo deles na unidade educativa?".

"Nunca ouvi nenhum comentário neste sentido, caso ouvisse, logo iria interferir"

(Excerto 1, resposta profissional Cristina)

"Nâo. Nunca percebi tratamento diferente".

(Excerto 2, resposta profissional Suelen)

"Nunca ouvi nenhum comentário depreciativo a respeito"

(Excerto 3, resposta profissional Prof)

"Nunca observei nenhum tipo de discriminaçâo em sala com seus pares".

(Excerto 4, resposta profissional Bianca)

"Nâo observei nenhum estranhamento".

(Excerto 5, resposta profissional Nanda)

"Que eu me lembre náo".

(Excerto 6, resposta profissional Maira)

Os excertos de 1 a 6 , bem como a maioria das respostas das profissionais ao questionário, evidenciam que as profissionais parecem nâo perceber o racismo no interior das instituiçôes de educaçâo, demonstrando com isso, que o mito da democracia racial no Brasil ainda se faz muito presente. Tal achado corrobora Pereira (2013) quando afirma que uma parcela significativa e expressiva da sociedade brasileira ainda compartilha a ideia de viver em uma naçâo nâo caracterizada por conflitos raciais abertos.

Historicamente, o mito da democracia racial no Brasil teve sua propagaçáo com a obra de Gilberto Freyre "Casa Grande e Senzala", publicada em 1933. Esta obra moldou o imaginário e a imagem do Brasil, personificando e materializando a miscigenaçâo (negro e branco) diante de uma relaçăo de otimismo na junçăo dessas duas raças, dando origem ao mulato, tipo este que para Freyre (2005) caracterizaria o Brasil. Para ele, o resultado da fusâo harmoniosa de tradiçóes e culturas antagônicas, passando por um processo de equilíbrio e possível ascensăo ao mulato, indivíduo mais humanizado e civilizado diante do embranquecimento, ou seja, dissemina a ideia de que a parte branca o salvou da barbárie e selvageria.

Deste modo, o mito da democracia racial vem dificultando a compreensâo da existência de desigualdades sociais orquestradas por conflitos raciais até hoje. O negro em sociedade ainda é classificado de forma negativa, desde muito cedo, o que é evidenciado na educaçáo infantil, conforme os excertos 7 a 11:

"[...] já ouvi alguns comentários racistas e xenofóbicos como "esses haitianos vem pra cá e tiram as vagas dos meus filhos", "que neguinho bonito", "ele nâo entende, é haitiano", entre outros".

(Excerto 7, resposta profissional Bia) 
"Da parte de alguns profissionais, em muitos momentos nâo tinham um olhar sensível para entender esta criança. Pois, cada criança tem suas especificidades, assim como a criança haitiana. Muitas vezes o profissional demonstrava certa discriminaçâo, nâo respeitando a cultura, os hábitos alimentares".

(Excerto 8, resposta profissional Júlia)

"[...] Já vivenciei situaçóes de uma criança negra dizer que é branca por conta que a professora falava que era branquinha feito leite. Uma situaçâo que me assustou por conta de a criança negar sua identidade por conta do que o adulto falava e fazia, em diversas situaçôes pintava os desenhos (com o lápis de cor rose) para que os mesmos assim pintassem, eu enquanto profissional do grupo falava que cada criança tem que se pintar como é, pois disponibilizávamos os lápis com todos os tons de pele. Situaçóes essas que espero nâo vivenciar mais, até porque a discriminaçâo e o preconceito estâo no adulto e no que ele fala para as crianças".

(Excerto 9, resposta profissional Elisa)

"[...]Entre as crianças já ocorreu o fato de duas meninas nâo quererem brincar com uma criança negra e haitiana, relatando que esta era feia. Entâo em roda expliquei que cada um tem seu tom de pele, sua cor e suas características e todos somos iguais com suas diferenças".

(Excerto 10, resposta profissional Ana)

"O fato que diferencia o haitiano do brasileiro é a cultura e a língua. Os haitianos sâo pessoas que os seus corpos vâo falar de suas identidades".

(Excerto 11, resposta profissional Tereza de Benguela)

Os excertos 7 e 8 demonstram a imposiçáo do padrăo do homem branco diante de suas características físicas como a estética harmoniosa a ser seguida perante um padrăo de branqueamento, assim como a sua cultura eurocêntrica em que o povo europeu desde a colonizaçâo impôs sua cultura e conhecimento. Dessa forma, tanto o nativo quanto o haitiano negro considerado etnicamente de cultura inferior săo vistos como seres que năo entendem, que degradam a cultura imposta e, assim, sâo invisibilizados, perpetuando a mesma ideia desde a colonizaçấo, desconsiderando o dito diferente. Quijano (2005) bem destaca que a ideia de raça passa a fazer sentido com os conquistadores outorgando uma conotaçăo racial, em que as relaçôes de dominaçáo impunham os padróes de identidade, sua cor branca e cultura considerada civilizada e evoluída como modelo. Nesse contexto, diferenças fenotípicas reduziram os negros a uma única identidade racial e colonial considerada negativa.

O excerto 9 evidencia a invisibilizaçăo da identidade cultural, racial e étnica das crianças haitianas. Conforme Abramowicz et al. (2006), o profissional da educaçâo precisa ter conhecimento e com isso, elementos para compreender as relaçôes raciais na cultura brasileira e decodificar as práticas discriminatórias produzidas no interior das instituiçóes de educaçăo infantil. No entanto, isso requer revisăo de valores e padróes concebíveis pelos profissionais e pela instituiçâo, estando estes longe da identidade de crianças negras, por meio de currículo embranquecido, cultura hegemônica e atitudes e padróes racistas naturalizados e cristalizados no cotidiano escolar. 
Gomes (2002) ressalta que as instituiçóes de educaçăo săo espaços destinados para além de aprendizagens e partilhas de saberes, mas também para compartilhamento de valores, crenças e hábitos, bem como de preconceitos raciais apresentados em interaçōes sociais negativas. Assim, as identidades săo construídas na interaçâo, ou seja, săo negociadas por toda uma vida no diálogo interior e com os outros. Nessas circunstâncias, a identidade negra é uma construçăo social, histórica e cultural repleta de conflitos e diálogos.

Desta forma, a formaçâo docente é lugar privilegiado, năo somente diante da importante discussâo sobre diversidade, diferença, identidade e relaçôes étnico-raciais, mas também como um lugar para se pensar açôes e implementaçâo de proposiçóes que possibilitem novos caminhos em busca do reconhecimento e valorizaçăo da identidade étnica e cultural nas instituiçóes. Por ser um lugar de formaçăo e processo educativo, a instituiçâo de educaçâo é um espaço que interfere na construçăo da identidade negra, podendo fortalecer e valorizar essa identidade ou estigmatizar, discriminar e até negá-la.

Desta forma, Gomes (2003, p. 171) ressalta que

Construir uma identidade negra positiva em uma sociedade que, historicamente, ensina ao negro, desde muito cedo, que para ser aceito é preciso negar-se a si mesmo, é um desafio enfrentado pelos negros brasileiros. Será que, na escola, estamos atentos a essa questáo? Será que incorporamos essa realidade de maneira séria e responsável quando discutimos, nos processos de formaçâo de professores, sobre a importância da diversidade cultural?

Neste sentido é preciso considerar a importância da articulaçăo entre cultura, identidade negra, diversidade, diferença e educaçăo na formaçâo docente, pois decodificar teorias e conceitos que compōem o currículo embranquecido além de práticas carregadas de estereótipos se faz essencial assim como o diálogo e proposiçōes pedagógicas positivas constantes diante da identidade cultural em sala de aula entre docentes e crianças.

Considerando que as crianças nâo nascem constituídas de preconceito e discriminaçăo, mas que tais atitudes vâo se internalizando mediante interaçóes sociais negativas, o excerto 10 provoca reflexóes diante do que seria feio para a crianças. Modelos estéticos relacionados ao bonito e ao belo também săo configurados socialmente diante de interaçôes familiares, escolares e até por meio das mídias (ABRAMOWICZ; OLIVEIRA, 2012). E manifestaçôes relacionadas a essa questăo merecem a atençáo de profissionais da educaçăo, principalmente considerando que uma simples conversa nâo mudará posturas e padrōes presentes no entorno da criança. Faz-se necessário buscar efetivar açôes mediante projetos que adotem a diversidade e a diferença em sala de forma contínua. Neste sentido, uma formaçăo docente que contemple toda a rede de ensino pode fazer a diferença em uma real educaçăo voltada para açôes antirracistas.

Quando a profissional de educaçăo expôe, no excerto 11, que "seus corpos vâo falar de suas identidades", trecho escolhido como título deste artigo, ela evidencia a questăo de os haitianos serem negros e com isso, seus corpos, perante sua cor, acarretam o racismo e permitem aflorar estereótipos atrelados à cor, de forma histórica em sociedade, os oprimindo inclusive em instituiçōes de educaçăo quando estas deveriam abraçar as diferenças e diversidades existentes. 
Dessa forma, é preciso desvelar e questionar mecanismos que calam e oprimem certo grupo em detrimento de outro. Assim, torna-se essencial privilegiar projetos e práticas que reconheçam e valorizem a diferença. E nesse contexto, investir em formaçâo docente revela-se como potente para preparar os docentes para refletir e trabalhar com a diversidade em ambiente educativo contribuindo assim para a transformaçáo de posturas enraizadas nos ambientes escolares. Pensar na formaçăo docente em uma perspectiva que abrace a diversidade é considerar o Brasil como multicultural e multirracial. Para tanto, o diálogo permanente se apresenta como instrumento indispensável já que o questionamento e decodificaçăo de teorias que compóem o currículo e a prática na sala de aula estâo comumente impregnados de preconceitos e estereótipos que calam e omitem os indivíduos que nâo se enquadram nos padrōes culturais impostos, reforçando desta forma a ideologia do embranquecimento centrada numa visăo etnocêntrica de mundo, em que a própria cultura dos colonizadores até hoje é concebida como única e correta.

A seguir, os excertos 12 e 13 destacam a inserçâo de crianças haitianas, demonstrando nas respostas das profissionais uma idealizaçăo negativa de imigrantes negros e nativos de um país, empregando estereótipos, assim, perpetuando a invisibilizaçáo do diferente perante sua cultura.

"As crianças que trabalhei eram muito bravas, quando contrariadas pareciam ficar com muita raiva, gritavam e levantavam a mâo para tentar nos bater, aos poucos foram tranquilizando-se e aprendendo a controlar seus sentimentos".

(Excerto 12, resposta profissional Maira)

"De um modo geral, sâo tranquilos, preferem brincar sozinhos, e por vezes apresentam dificuldade em compreender algumas regras estabelecidas na rotina da unidade".

(Excerto 13, resposta profissional Sol)

É imprescindível para o profissional de educaçâo compreender que as crianças haitianas vêm de um país com cultura, idioma, tradiçôes e entre outras diferenças inerentes a cada povo, de tal modo que reconhecer, respeitar e visibilizar essa diversidade é essencial para acolher e respeitar o outro como igual em direitos, sendo esta diversidade complementar à formaçáo humana. Os excertos 12 e 13 corroboram a conclusáo de Pizzinato e Sarriera (2003) de que é importante refletir sobre a inserçâo da criança imigrante perante a qualidade de fatores ambientais positivos que a ela sâo permitidos ou năo nos intercâmbios com demais crianças e com os profissionais da educaçâo. A autoestima dessas crianças pode ser abalada significativamente diante de acontecimentos diários que podem ser representados de maneira explicita ou implícita assinalando que seu grupo étnico ou familiar náo se enquadra no padrâo estabelecido possuindo menor status diante dos demais. Diante desta triste constataçâo, as crianças reagem de maneira muitas vezes incompreendida pelos profissionais da educaçăo. No entanto, é preciso lembrar que essas crianças estâo se inserindo em uma nova cultura, com língua diferente e, assim, regras săo muitas vezes incompreendidas por elas.

Desta forma, profissionais da educaçăo precisam reconhecer, visibilizar e se sensibilizar com a diversidade e as diferenças que encontram em sala de aula, pois para 
a criança imigrante é de suma importância, para sua autoestima, o modo como sua identidade cultural é reconhecida e valorizada. Assim, destaca-se que a formaçăo dos profissionais atuantes na educaçăo precisa refletir e debater constantemente a diversidade e a diferença para transformaçōes na busca por uma educaçăo antirracista.

Considerar que na educaçăo infantil năo existe racismo é ignorar que as instituiçóes educacionais estăo atreladas ao racismo estrutural, que se enraíza e se estrutura nos sujeitos de forma tăo naturalizada que pode nâo ser percebido. Segundo Almeida (2019), o racismo transcende o segmento individual, principalmente diante do aparato institucional que controla, determina e impóe regras e padróes que as instituiçóes, como escola, igreja e Estado, resguardam, ou seja, as instituiçôes sâo a materializaçấo dessa estrutura social que tem no racismo seu elemento natural.

É preciso refletir sobre a história e a cultura afro-brasileira diante da formaçăo e desenvolvimento desta sociedade, conforme determinaçăo da Lei 10.639/2003, bem como da cultura educacional diante da educaçáo para as relaçóes étnico-raciais, que nâo considera a diversidade existente, invisibilizando o diferente. Diante de um padrăo homogêneo em instituiçôes de educaçăo infantil, é preciso refletir e considerar a diversidade existente e propor realmente uma educaçăo igualitária e democrática que se proponha ao desenvolvimento integral das crianças perante uma sociedade que abrace a todos.

\section{CONSIDERAÇÕES FINAIS}

Este artigo, ao reportar um recorte de uma pesquisa de mestrado, procurou discutir o importante papel das instituiçôes de educaçăo infantil como espaço para promover o desenvolvimento integral das crianças, assim como um lugar para construçấo e efetivaçăo de identidades negras positivas, perante um trabalho de reconhecimento ao diferente e à diversidade étnico-racial existente diante de uma educaçâo antirracista e com base no multiculturalismo.

De tal modo, evidencia-se a necessidade de uma verdadeira transformaçăo nos sistemas de educaçăo mediante um currículo pautado em discursos e açōes que visem o reconhecimento da diversidade existente na sociedade e assim, possa efetivamente haver uma mudança nas posturas arraigadas no interior das instituiçôes de educaçăo, que tem um trabalho comumente embasado na manutençâo de padróes homogeneizados, diante de um currículo embranquecido e eurocêntrico.

Em busca de uma educaçâo antirracista, destacam-se políticas públicas embasadas nas Leis $n^{0} 10.639 / 2003$ e $n^{0} 11.645 / 2008$ que incluem no currículo nacional a história e cultura afro-brasileira e indígena, resgatando a contribuiçâo do povo negro e indígena para a história e desenvolvimento do Brasil, contribuindo assim para a construçấo de uma identidade positiva a qual historicamente foi vista e tratada como subalternizada.

$\mathrm{Na}$ perspectiva de romper com relaçōes de poder estruturais constituídas historicamente na sociedade e na consciência de seus indivíduos, urge-se por políticas educacionais que buscam a garantia de direitos humanos e justiça social, diante da preconizaçấo e compreensâo de que todos os sujeitos têm direito à sua identidade e, com isso, à diferença. Portanto, é dever das instituiçōes de educaçâo perante uma 
instruçăo formal reconhecer e valorizar a diversidade e as diferenças, pondo assim em prática uma educaçăo para as relaçôes étnico-raciais.

Partindo-se do pressuposto de que as relaçóes étnico-raciais precisam ser evidenciadas, refletidas e trabalhadas cotidianamente na educação infantil de modo positivo, num trabalho voltado à sensibilizaçấo e ao reconhecimento da diversidade, as discussôes desta pesquisa evidenciaram como principais resultados que: (1) comumente a diversidade e o trato da questăo étnico-racial continuam silenciados no interior das instituiçôes, ou seja, as instituiçôes ainda se embasam em uma postura homogeneizadora invisibilizando e abafando o diferente; (2) o silenciamento ao diferente no interior das instituiçóes ainda é confundido comumente por profissionais da Educaçáo como desconhecimento da discriminaçáo racial, quando deveria ser compreendido o mito da democracia racial ainda muito presente na realidade brasileira; (3) as instituiçóes de educaçăo infantil e os docentes carecem de considerar a diversidade cultural existente e reconhecer a sociedade brasileira como multicultural, quando as instituiçóes ainda se solidificam em uma base monocultural, evidenciando a imposiçăo do padrăo da cultura europeia e branca no Brasil; e por fim, (4) uma educaçấo antirracista que considere a diversidade precisa viabilizar práticas pedagógicas que abracem a diversidade cultural e a identidade negra em vez de abafá-las e invisibilizá-las. Um possível caminho está numa formaçâo docente contínua que procure sensibilizar os profissionais da educaçăo à pluralidade, considerando a diversidade e as diferenças.

Em suma, os resultados revelam que crianças negras e pertencentes a culturas ditas diferentes do padrâo estabelecido ainda săo comumente invisibilizadas no interior das instituiçóes por profissionais que năo reconhecem a diversidade existente. Assim, é de extrema necessidade formar profissionais que se sensibilizem às diferenças e reconheçam a diversidade cultural e racial existente nos espaços em que ocupam. Da mesma forma, é preciso ampliar esta discussáo por meio de outros trabalhos e pesquisas que possam trazer mais subsídios para a construçáo de uma possível mudança perante esta realidade. 


\section{REFERÊNCIAS}

ABRAMOWICZ, Anete; SILVÉRIO, Valter Roberto; OLIVEIRA, Fabiana de; TEBET, Gabriela Guarnieri de Campos. Trabalhando a diferença na educaçáo infantil. Sâo Paulo: Moderna, 2006.

ABRAMOWICZ, Anete; OLIVEIRA, Fabiana de. As relaçōes étnico-raciais e a sociologia da infância no brasil: alguns aportes. In: BENTO, Maria Aparecida Silva. Educacăo infantil, igualdade racial e diversidade: aspectos políticos, jurídicos, conceituais. Săo Paulo: Centro de Estudos das Relaçóes de Trabalho e Desigualdades - CEERT, 2012, p. 47-64.

ALMEIDA, Silvio. Racismo estrutural. Săo Paulo: Pólen, 2019.

BRASIL. Constituiçăo Federal da República Federativa do Brasil (1988). Disponível em: 〈http://www.planalto.gov.br/ccivil_03/constituicao/constituicao.htm〉. Acesso em: 05 jun. 2020.

BRASIL. Lei 10.639, de 09 de janeiro de 2003. Altera a Lei no 9.394, de 20 de dezembro de 1996, que estabelece as diretrizes e bases da educaçăo nacional, para incluir no currículo oficial da Rede de Ensino a obrigatoriedade da temática "História e Cultura Afro-Brasileira", e dá outras providências. Disponível em: <http://www.planalto.gov.br/ ccivil_03/leis/2003/110.639.htm>. Acesso em: 20 jan. 2021.

BRASIL. Lei $n^{\circ}$ 11.645, de 10 de março de 2008. Modifica a Lei ${ }^{\circ}$ 10. 639/2003 para incluir no currículo oficial da rede de ensino a obrigatoriedade da temática "História e Cultura Afro-Brasileira e Indígena". Disponível em: <http://www.planalto.gov.br/ccivil_03/_Ato2007-2010/2008/Lei/L11645.htm>. Acesso em: 6 nov. 2020.

FREYRE, Gilberto. Casa Grande \& Senzala: formaçăo da família brasileira sob regime de economia patriarcal. Sáo Paulo: Global, 2005.

GIL, Antônio Carlos. Métodos e técnicas em pesquisa social. 6. ed. Sáo Paulo: Atlas, 2008.

GODOY, Arilda Schmidt. Pesquisa qualitativa: tipos fundamentais. Revista de administraçăo de empresas, v. 35, n. 3, p. 20-29, 1995. Disponível em: <https://www.scielo.br/ pdf/rae/v35n3/a04v35n3.pdf>. Acesso em: 16 out. 2020.

GOMES, Nilma Lino. Educaçăo e identidade negra. Aletria, v. 9, p. 38-47, 2002. Disponível em: <https://periodicos.ufmg.br/index.php/aletria/article/view/17912/14702>. Acesso em: 29 jan. 2021.

GOMES, Nilma Lino. Educaçăo, identidade negra e formaçăo de professores/as: um olhar sobre o corpo negro e o cabelo crespo. Educaçâo e Pesquisa, Sáo Paulo, v. 29, n. 1, p.167182, jan./jun. 2003. Disponível em: <https://www.scielo.br/pdf /ep/v29n1/a12v29n1. pdf>. Acesso em: 14 out. 2020.

GOMES, Nilma Lino. Relaçôes Étnico-raciais, educaçâo e descolonizaçâo dos currículos. Currículo sem Fronteiras, v. 12, n. 1, p. 98-109, 2012. Disponível em: <http://www.curriculosemfronteiras.org/vol12isslarticles/gomes.pdf>. Acesso em: 20 set. 2020.

JAMES, C. L. C. Os Jacobinos Negros. Toussaint L' Ouverture e a Revoluçáo de Sâo Domingos. Săo Paulo: Boitempo, 2000. 
MAGALHĀES, Luís Felipe Aires. O Haiti é Aqui: Sub Imperialismo Brasileiro e Imigrantes Haitianos em Santa Catarina - SC. Revista Brasileira de Estudos Latino-Americanos, v. 5, n.1, p. 13-43, 2015. Disponível em <http://www.nexos.ufsc.br/index.php/rebela/ article/view/2650/1698>. Acesso em: 22 ago. 2020.

MAINARDES, Jefferson. A ética na pesquisa educaçăo: panorama e desafios pós-resoluçăo CNS no 510/2016. Educaçăo, v. 40, n. 2, p. 160-173, 2017. Disponível em: 〈https:// www.redalyc.org/pdf/848/84852464004.pdf>. Acesso em: 19 out. 2020.

MARTINS, Heloisa Helena T de Souza. Metodologia qualitativa de pesquisa. Educaçăo e Pesquisa. Săo Paulo, v. 30, n. 2, p. 289-300, 2004. Disponível em: <https://www.scielo.br/ pdf/ep/v30n2/v30n2a07.pdf>. Acesso em: 16 jun. 2020.

PEREIRA, Amílcar Araújo. 0 mundo negro: Relaçōes raciais e a constituiçăo do movimento negro contemporâneo no Brasil. Rio de Janeiro: Pallas/Faperj, 2013.

PIZZINATO, Adolfo; SARRIERA, Jorge Castellá. Competência social infantil: análise discriminante entre crianças imigrantes e năo imigrantes no contexto escolar de Porto Alegre. Psicologia em Estudo, v. 8, n. 2, p. 115-122, 2003. Disponível em: <https://www. scielo.br/pdf/pe/v8n2/v8n2a11>. Acesso em: 05 nov. 2020.

QUIJANO, Anibal. Colonialidade do poder, Eurocentrismo e América Latina. In: LANDER, Edgardo (org.). A colonialidade do saber: eurocentrismo e ciências sociais. Perspectivas Latinoamericanas. Buenos Aires: CLACSO, 2005, p. 107-130.

RIBEIRO, Djamila. Pequeno manual antirracista. Săo Paulo: Companhia das Letras, 2019.

SCARAMAL, Eliesse dos S. T. Haiti: fenomenologia de uma barbárie. Goiânia: Cânone Editorial, 2006.

SCHWARCZ, Lilia Moritz; GOMES, Flávio dos Santos. Introduçăo. In: SCHWARCZ, Lilia Moritz; GOMES, Flávio dos Santos. (org) Dicionário da escravidăo e liberdade: 50 textos críticos. Rio de Janeiro: Companhia das Letras, 2018. 